\title{
Effect of Maize Flour and Lactobacillus acidophilus Towards Save Tempe Soybean
}

\author{
Laela Noor Faizah ${ }^{1} *$, Siti Harnina Bintari ${ }^{2}$, Retno Sri Iswari ${ }^{2}$ \\ ${ }^{1}$ Postgraduate Student; ${ }^{2}$ Postgraduate Lecturer, Semarang State University \\ UNNES Postgraduate Campus Jl. Kelud Utara III Semarang 50237 \\ Email*: deliepde93@students.unnes.ac.id
}

\begin{abstract}
Tempe is a traditional Indonesian food product made from soybeans (Glycine max) which is processed through the process of fermentation by mold. Tempe has constraints in its utilization, namely in its short shelf life and has a perishable nature. The purpose of this study was to determine the effect of corn flour on the storability of tempe by the addition of Lactobacillus acidophillus. This research method uses true experimental with two factors. The first factor was Lactobacillus acidophillus $1.5 \%(\mathrm{v} / \mathrm{w}$ ) as treatment and $0 \%(\mathrm{v} / \mathrm{w}$ ) as control. The second factor is the concentration of corn flour $(\mathrm{w} / \mathrm{w})$ respectively $0 \%(\mathrm{w} / \mathrm{w})(\mathrm{T} 0), 0.4 \%(\mathrm{w} / \mathrm{w})(\mathrm{T} 1), 0.8 \%(\mathrm{w} / \mathrm{w})(\mathrm{T} 2)$ and $1.2 \%(\mathrm{w} / \mathrm{w})(\mathrm{T} 3)$. The results showed that the addition of $1.5 \%$ Lactobacillus acidophillus and $0.8 \%$ corn flour to soybean tempeh was able to increase the shelf life of soy tempeh for a maximum among others 4 days.
\end{abstract}

Keywords: soytempeh, Lactobacillusacidophillus, corn flour

\section{INTRODUCTION}

The human body needs a variety of nutrition include protein, fat, calcium, phosphorus, carotene, and vitamin B1 (Pusido BSN, 2012). These nutrients can all be obtained from tempeh. Tempe has long been recognized as a food with a high nutritional content value. Tempe generally consumed as snacks companion rice.

Tempe is a traditional Indonesian food products made from soybeans (Glycine max) is processed through fermentation by molds. Mold growing on soy can hydrolyze carbohydrates, proteins, and fats into simpler forms that tempe more easily digested by the body, substances degrade anti nutrition, generate specific aroma and flavor tempeh (Susanto and Saneto, 1994). Tempe has constraints in its utilization, that is the short shelf-life and is easily damaged (perishable). Fresh Tempe stored at room temperature can only survive two days, while the low-temperature storage can last one week (Widowati et al., 2004). This is also confirmed by Kasmidjo (1990) tempe stored at room temperature have a short shelf life is 48 hours and after that,tempeh will decay so that it cannot be consumed.

Tempe eligible consumption must be unity of soy beans in white mycelium uniform bond and filled the whole body tempe form a dense arrangement, compact, and has not raised the smell of ammonia. Tempe already smelling ammonia, rot, wet and slimy with a brownish color, as well as the mycelium grows unevenly it is not feasible anymore tempe consumption.

The formation of a foul odor is a source of major damage (Sarwono, 2002). Tempeh decay is marked with increasing $\mathrm{pH}$ value. Efforts to prevent an increase in the $\mathrm{pH}$ value of tempeh can be done with the addition of lactic acid bacteria in the manufacture of tempeh. The lactic acid bacteria will produce lactic acid that serves to maintain the $\mathrm{pH}$ value of tempeh. Lactic acid bacteria also produce antibacterial that is often referred to as a bacteriocins, which can inhibit the growth of spoilage bacteria (Fardiaz, 1988). Bacteria capable of producing lactic acid, especially of the genus Lactobacillus, Bifidobacterium, and a few other types of bacteria.

One of the lactic acid bacteria of the genus Lactobacillus is Lactobacillus acidophillus species. The existence of Lactobacillus achidophillus in fermentation will produce lactic acid that serves to maintain the $\mathrm{pH}$ value of tempeh and be antimicrobial that can inhibit the growth of spoilage and pathogenic microbes. Media such as corn flour in the manufacture of soybean tempeh as Lactobacillus achidophillus energy sources is expected to extend the shelf life and maintain the characteristics of soybean tempeh tempeh unfit for consumption.

\section{RESEARCH METHODS}

\section{Tools and materials}

The main materials used are imported soybean (Glycine max) and tempe yeast obtained Prima brand of soybean production center in the village of thematic villages Lamper central Semarang, egafood brand corn flour, Lactobacillus acidophillusin the form of a pure culture in order to erect obtained in the form of Inter-University Center for Food and Nutrition UGM, UHT milk, MRSA, ME, and EA. The tools used include baskets, stoves, winnowing large, pans, buckets, mixers wood, strainer, crusher soybean, colony counter, thermometer, shaker incubator, BSC, Bunsen, analytical balance, autoclaves, tubular flask, ose round, test tubes, mortar pestle, 
micropipette, petri dishes, beakers, and other tools for organoleptic test.

\section{Research methods}

Research compiled using true experimental method with two factors. The first factor is the culture of Lactobacillus acidophilus $0 \%$ (v / w) (L0) as the control and $1.5 \%(\mathrm{v} / \mathrm{w})(\mathrm{L} 1)$ as a treatment. The second factor is the concentration of corn starch $(\mathrm{w} / \mathrm{w})$ respectively $0 \%$ (w / w) (T0), 0.4\% (w / w) (T1), 0.8\% (w / w) (T2) and $1.2 \%(\mathrm{w} / \mathrm{w})(\mathrm{T} 3)$. Observations were made on each attribute consisting of 6 samples. Observations were made every day after tempe fermented for 48 hours. Data from each attribute then recorded and retrieved the number of samples that still persist, as well as the data presented in the form of a diagram.

Preparation of Lactobacillus acidophillus starter started from making as much 3,41gr MRSA media and diluted with $50 \mathrm{ml}$ of distilled water and then sterilized. Pure culture of Lactobacillus acidophilus obtained in order to erect taken 1ose then inoculated onto surfaces that MRSA sterile on the petridish prepared and incubated for $24 \mathrm{~h}$ at $37^{\circ} \mathrm{C}$ Lactobacillus acidophilus cultures that grow on the surface so that MRSA was taken by ose then put into $150 \mathrm{ml}$ UHT milk sterile and incubated for $24 \mathrm{~h}$ at $37^{\circ} \mathrm{C}$. This culture is ready for use.

The observations made are determining the shelf life and organoleptic observations of simple microbes. Determination of shelf life to do to get treatment tempeh with the longest shelf life who still have physical characteristics according to the standard ISO normal tempeh (soybean typical white color, compact and dense texture, and aroma tempeh). Observation begins every day after tempeh fermented for 48 hours of the life of 24 hours, 48 hours, and so every 24 hours until the tempeh undergo physical changes. Physical changes observed using sensory descriptive. Observations of microbes performed once after tempeh fermented for 48 hours, the samples were inoculated diluted and pour plate technique that uses bacteria cultivation medium into a petri dish for bacterial growth of L. casei, E. coli and Rhizopus sp with casting techniques. Observations microbes began after incubated at a temperature of space between $34^{\circ} \mathrm{C}-37^{\circ} \mathrm{C}$ for 48 hours in an agar medium, and then counted the total number of bacteria, the data obtained are discussed in the descriptive analysis. Furthermore, the best treatment will be tested organoleptic simple to the taste and appearance of soybean tempeh structure using the five senses directly. The data obtained are discussed using descriptive analysis.

\section{RESULTS AND DISCUSSION}

The main purpose of the study is to determine the durability of soybean tempeh with the addition of
Lactobacillus acidophillus and fermented corn meal after 48 hours, observations every 24 hours until it was discovered the old store that shows a change in the organoleptic properties that do not meet standards. Observations were made every attribute that consisted of 6 samples, viewed using the five senses directly. The observed parameters of the six samples each attribute is color, smell, and texture, and then the samples still meet SNI counted and recorded. The observation of the shelf life of soybean tempeh presented in diagram 1.

\section{Durability Tempeh}

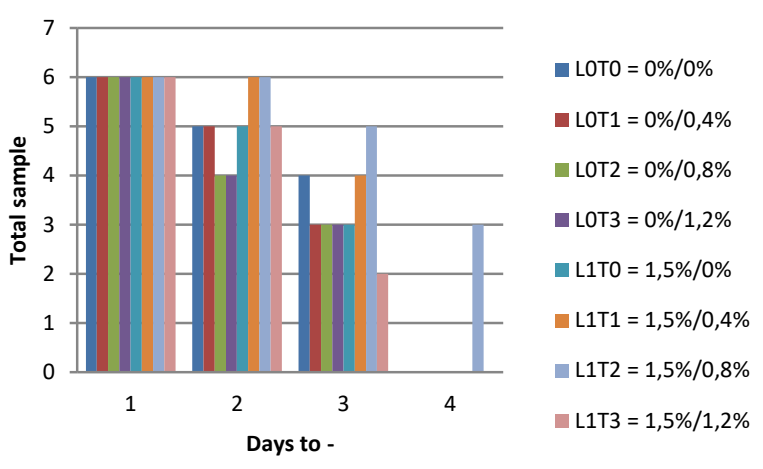

Figure 1. Diagram Observations shelflife of soybean tempeh research

Tempe on the first day of the diagram can be seen to have conditions that are the same as the control without the addition of tempeh L. acidophillus and cornstarch. In all the attributes, all six samples still show the colors, smells, and textures typical of normal tempe. While the 2nd day began to show the difference between the number of control samples with samples treated with the addition L.acidophillus and cornstarch. Tempe without giving L.acidophillus on L0T0, L0T1, L0T2, L0T3 remaining number of samples less than the tempe plus L.acidophillus. However, on the 3rd day LOT0 remaining number of samples equal to the number of samples L1T1, even more than the number of samples L1T0 and L1T3, but still fewer than the number of samples remaining from L1T2.

The longer the period of storage, the physical condition of soybean decreased. Based on observations in soybean L. achidophillus L1T2 plus $1.5 \%$ and $0.8 \%$ corn flour has a maximum endurance to 4 days and is still suitable for consumption. While the concentration of the same bacteria L. acidophillus of $1.5 \%$ on research Hamzah using a $0.4 \%$ concentration of corn starch has been able to improve the durability of soybean tempeh to 112 hours. Based on these results, we can conclude that the shelf life of tempeh can be influenced by the type of lactic acid bacteria and growth media used.

L.achidophillus at a concentration of $1.5 \%$ and $0.8 \%$ corn flour allegedly antibacterial generated numbers are sufficient to inhibit spoilage bacteria in soybean treatment. L.acidophillus able to produce lactic acid, 
lactic acid produced can lower the $\mathrm{pH}$ value of growth becomes more acidic environment (Winarno and Fernandez, 2007). Acidic environment is not favored by many bacterial pathogens or spoilage bacteria, which can inhibit the growth of bacteria (Kanbe, 1992). Corn flour serves as a nutrient for Lactobacillus acidophillus to growth by utilizing carbohydrates in corn starch as an energy source. At a concentration of $0.8 \%$ corn flour was thought to be sufficient to meet the energy needs L.achidopillus.

According Suharyono (2008) flour that contains high levels of carbohydrates which also acts as a nutrient substrate for Rhizopus grow and can produce a high mycelium. It is thought to cause the tempe L1T3 on the 3rd day more visible decay, leaving only 2 samples were still fit for consumption compared to the number of soybean samples were not given Lactobacillus acidophillus. The concentration of corn flour 1.2\% L1T3 too much thought to provide nutrients for Rhizopus and L.acidopillus compete in getting the nutrients that cause over the tempe fermented soybeans.

Table 1. Summary of test observations L. acidophillus, E. Coli, Rhizopussp.

\begin{tabular}{llll}
\hline Treatment & L. acidophillus & E. coli & Rhizopus \\
\hline L0T0 & 0 & Not exist & Exist \\
L0T1 & 0 & Not exist & Exist \\
L0T2 & 0 & Not exist & Exist \\
L0T3 & 0 & Not exist & Exist \\
L1T0 & $2.1 \times 10^{5}$ & Not exist & Exist \\
L1T1 & $4.4 \times 10^{5}$ & Not exist & Exist \\
L1T2 & $6.4 \times 10^{5}$ & Not exist & Exist \\
L1T3 & $7.8 \times 10^{5}$ & Not exist & Exist \\
\hline
\end{tabular}

Total L.acidophillus in soybean that has been fermented to 48 hours, can be seen in Table 1. the results showed that the addition of cornstarch affect the increase in total Lactobacillus acidophillus. The increase in total bacteria L.acidophillus directly proportional to the amount of corn flour are added. The higher the concentration the concentration of corn flour are added, the higher the total bacterial L.acidophillus growing. This is presumably because the carbohydrates in corn flour are added as an energy source for bacterial growth L.acidophillus.

Carbohydrates are an essential nutrient for the growth of lactic acid bacteria for glucose in carbohydrates is the energy to stimulate the growth of bacteria L.acidophillus. With the absence of glucose, the bacteria can grow quickly in large quantities. Glucose is used for the metabolism of lactic acid bacteria during the growth of bacteria.

Observation of microbial sampling occurs only once in the soybean samples that have undergone fermentation 48 hours after fermentation. So it can not conduct further observations of the interactions between the total concentration of cornstarch, L.acidophillus and tempe Rhizopus on samples after 24 hours later.
Observations of $E$. coli in the sample tempeh after incubation for 48 hours at a temperature of between 34$37^{\circ} \mathrm{C}$ space gained that all attributes not indicate the growth of E. coli on an agar medium. The absence of E. coli growing on media show that tempeh is already hygienically in the manufacturing process and unfit for consumption.

Table 2. Average yield a total score of organoleptic method of hedonic.

\begin{tabular}{llll}
\hline Treatment & Flavour & $\begin{array}{l}\text { Appeareance } \\
\text { structure }\end{array}$ & $\begin{array}{l}\text { Overall } \\
\text { reception }\end{array}$ \\
\hline L0T0 & 4,3 & 4,7 & 4,5 \\
L0T1 & 3,5 & 3,7 & 3,6 \\
L0T2 & 2,5 & 2,5 & 2,5 \\
L0T3 & 3,3 & 3,3 & 3,3 \\
L1T0 & 3,3 & 3,7 & 3,5 \\
L1T1 & 3,3 & 3,5 & 3,8 \\
L1T2 & 4,7 & 4,3 & 4,5 \\
L1T3 & 2,7 & 3,3 & 3 \\
\hline 0-1 = Very dislike & $2,1-3=$ A little like & $4,1-5=$ really like \\
1, -2 - Dislike & $3,1-4=$ just like &
\end{tabular}

Organoleptic testing conducted in soybean that has been fermented for 48 hours. Presentation tempeh done without frying and without the addition of flavorings / other spices to the panelists. In testing the organoleptic simple, the panelists instructed to fill out a questionnaire with the method of hedonic scale of 1 (strongly dislike), 2 (dislike), 3 (a bit like), 4 (just like), and 5 (really like), results acquired totaled and averaged. Best determination based on overall organoleptic test results can be seen on table 2.

Based on the observation of the results of the questionnaire hedonic total tempeh, samples L1T1 L0T0 and highly preferred by the panelists. This is because the tongue is more familiar with the taste panelists normal tempe commonly consumed daily, while there was a slight sense of tempeh L1T1 sour taste but it added to the positive response of the panelists for giving a fresh sensation on the tongue. Sour taste produced by L.acidophillus on suspected combination L1T1 tempeh until enough so as not produce a sour taste high or too low. While the sample L1T3 only received a score of 3 for the panelists regard the overall acceptance sample more sour.

L0T2 samples and samples LOT1 slightly favored and well liked LOT3 panelist for the overall acceptance in soybean tasted a bit sweet for allegedly addition of cornstarch. This may be because the tongue panelists familiar with the savory taste tempe compared with tempeh sweet. According Winarno (2002) suata reception foodstuffs depends on natural factors, geographical, and social aspects.

\section{CONCLUSION}

Based on the research that has been done can be concluded that the concentration of Lactobacillus 
acidophillus $1.5 \%$ and $8 \%$ corn flour has a shelf life that is best for 4 days and can be accepted by the panelists in the organoleptic test.

\section{REFERENCES}

Amalia, Risa; Suharyono; Sussi Astuti. 2018. Kajian Penggunaan Tepung Terigu dan Suhu Rendah Penyimpanan Terhadap Masa Simpan Dan Sifat Sensori Tempe Kedelai Probiotik Dengan Lactobacillus casei. Skripsi Fakultas Pertanian UNILA. Agustus 2018

Aptesia, Lidya Tri; Suharyono; Harun Al Rasyid. 2013. Pemanfaatan Lactobacillus Casei Dan Tapioka Dalam Upaya Menghambat Kerusakan Tempe Kedelai. Jurnal Teknologi Industri dan Hasil Pertanian Volume 18 No.2, September 2013

Fardiaz, S. 1988. Fisiologi Fermentasi. Bogor: Pusat Antar Universitas Lembaga Sumberdaya Informasi. Institut Pertanian Bogor
Hamzah, Febri; Marniza, Samsul Rizal. Pengaruh Konsentrasi Lactobacillus acidophilus dan Tepung Sagu Terhadap Umur Simpan dan Sifat Sensori Tempe Kedelai. Jurnal Inovasi dan Pembangungankelitbang volume 02 No.03

Kanbe, M. 1992. Functions of Fermented Milk: Challenges for The Health Sciences (Ed. Y. Nakazawa and A. Hosono), Elsevier Appl. Publ., london.

Rizal, Samsul; FibraNurainy; MelzwFitriani. 2013. Pengaruh Penambahan Sari Buah Jambu Biji Merah (Psidiumguajava L.) Dan Glukosa Terhadap Total Bakteri Laktat Dan Karakteristik Organoleptik Minuman Sinbiotik Cincau Hijau (Premnaoblongifolia Merr). Jurnal Teknologi Industri dan Hasil Pertanian Volume 18 No.2, September 2013

Sarwono, B. 2002. Membuat Tempe dan Oncom. Penebar Swadaya. Jakarta.

Winarno, F.G. 1992. Kimia Pangan dan Gizi. Gramedia. Jakarta. $43 \mathrm{hlm}$. 